\title{
DAILY AND INTERNAL MIGRATION OF SELECTED ETHNIC GROUPS IN MUNICIPALITIES AND TOWNS OF THE REGION OF VOJVODINA (SERBIA)
}

DOI: http://dx.doi.org/10.18509/GBP.2018.44 UDC: 314.15-026.48(497.113)"2001/2015"

\author{
Milka Bubalo-Živković \\ Bojana Kalenjuk \\ Tamara Lukić \\ Bojan Đerčan \\ University of Novi Sad, Faculty of Sciences, Department of Geography, Tourism and Hotel \\ Management, Novi Sad, Serbia
}

\begin{abstract}
The region of Vojvodina, a region in the north of the Republic of Serbia, represents a geographical area that is ethnically very diverse. A large number of ethnic groups in the area of Vojvodina, which are present today, is the result of migrations for centuries that took place towards these areas and from these areas. The aim of this paper is to determine which ethnic group, according to the 2011 Census data, was the most active in the daily movement, which was dominant in internal migration. Mobility of the population depends on the activity pursued by them, but also on the educational level. Nine ethnic groups in the region of Vojvodina (Serbs, Hungarians, Slovaks, Croats, Bunjevci, Roma, Romanians, Ruthenians and Montenegrins) have been identified in the work, surveying primary activity of the population, level of education of the largest part of the ethnic group, and then the participation of the daily migrants by separate ethnic groups. Socioeconomic processes in the structure of the economy that took place in the second half of the $20^{\text {th }}$ century led to the globalization of activities across ethnic groups, but certain differences were also sustained in the twenty-first century, which is the goal of this paper, to determine the differences between ethnic groups. The analysis used the data from the Statistical Office of the Republic of Serbia obtained through the special processing of the 2011 Census data. The mentioned ethnic groups are separated by higher shares (Hungarians, Slovaks, Roma and Croats) or by small numbers, but they are specific ethnic groups in Vojvodina (Bunjevci and Ruthenians).
\end{abstract}

Key words: daily migration, internal migration, ethnic groups, Region of Vojvodina

\section{INTRODUCTION}

Population migration is conditioned by numerous factors, such as those related to the natural geographic characteristics of a given space, as well as to the socio-geographical characteristics, historical events, political turmoil, and many other factors. Some ethnic groups are more likely to migrate than others. And this is one of the reasons for the different demographic characteristics of certain ethnic groups in some area, which has a great influence on the sustainability of a certain population.

The entire area of Serbia, since it is located in the Balkans, the sphere of interest of many great powers, has been affected by the constant migration through history, the emigration of members of one ethnic group, and the immigration of some other ethnic groups. This 
left rich historical and archaeological localities that today confirm the constant migration movements in this area and the impact on the genetic modification of population that once lived in this area [1]. And the northern region of Serbia, Vojvodina, was also hit by numerous people who came or left peacefully and voluntarily, but also by forced migrations. These centuries-old movements of people in this region have left an extraordinary diverse ethnic image, which is a great asset of this area, which should be preserved by the present and future generations. Permanent centuries-old migrations caused that today more than 20 different ethnic groups live in the area of Vojvodina. Over time, the domination of certain ethnic groups has shifted. Today, the Serbian population is the largest one in Vojvodina, $66.8 \%$ of the total population of Vojvodina. The second ethnic group in the total number of inhabitants is Hungarians $(13.3 \%)$, followed by Slovaks (2.6\%), Croats (2.4\%), Roma (2.2\%), Romanians (1.3\% Montenegrins $(1.1 \%)$ and other ethnic groups that participate with less than one percent [2], [3].

In the last decades, there has been a decrease in the number of members of almost all ethnic groups in the area of Vojvodina due to reduced natural increase and intensive emigration. The emigration, from the territory of Serbia and even Vojvodina, was intensified due to war events during the 1990s, poor economic conditions, unemployment and political turmoil [4], [5]. These factors have led some ethnic groups to have a greater or lesser outflow of inhabitants from Vojvodina, and on the other hand, there is the immigration of members of certain ethnic groups (Roma, Russians). The aim of this research is to determine which ethnic groups are the most movable, and which have the most autochthonous population, that is, which groups are most closed and are not prone to migration, daily movements or permanent resettlements.

\section{MATERIAL AND METHODS}

The paper uses data from the Republic Institute for Statistics on ethnicity from the 2011 Census. Data on the ethnic composition of the population are relevant for monitoring migratory flows and other characteristics of ethnic communities, as well as for improving strategies and improving the status of members of certain ethnic groups. According to international recommendations, the question on ethnicity is not one of the main features of a population, for that reason each country decides on its own whether it will collect these data. The question on the form is formulated as an open-ended question with a legal instruction that, according to Article 47 of the Constitution of the Republic of Serbia, citizens are not obliged to declare their ethnicity [6]. It is precisely this reason, freedom of expression of nationality, which leads to varying number of members of particular ethnic groups. This brings analysts into a dilemma and they hardly find reasons for increasing or decreasing size of certain ethnic groups. According to the Census 2011 methodology, daily migrants are all persons working or studying outside their habitual place of residence, but everyday or several times a week they return to it [7].The data used for this research is the result of additional data processing. The paper used descriptive statistics for data processing, and then the obtained results were analyzed. The migration analysis was carried out only for the ethnic groups that are numerous in the area of Vojvodina, that is, those with more than one percent share (Serbs, Hungarians, Slovaks, Croats, Roma, Romanians and Montenegrins). In addition, migration of two other ethnic groups, Ruthenians and Bunjevci, typical for the region of Vojvodina, were also analyzed. 


\section{RESEARCH RESULTS AND DISCUSSION}

Vojvodina experienced migration during the 18th, 19th and 20th centuries, which left a visible influence on ethnic diversity to this day. During this period there was a decline in the number of certain ethnic groups, such as the Germans, who were significantly more numerous before the Second World War, and the immigration of members of some other ethnic groups. In this post-war period, the number and share of the Serbian population significantly raised due to colonization after the First and Second World War, and the forced eviction from the territory of Croatia and Bosnia and Herzegovina in the 1990s, when Serbia became the destination of more than 650,000 refugees [8]. The Serbian population immigrated to the region of Vojvodina in the 1990s and in later events in the southern province of Kosovo and Metohija after 1999. All this caused that the Serbs today in Vojvodina have the largest share of migrants $(51.1 \%)$, and the smallest share of indigenous population (48.9\%). Montenegrins are also a mobile ethnic group. In them migrants participate with $49.4 \%$ of the total number of this population. The most closed ethnic group in Vojvodina are the Slovaks. Only every fifth member of this ethnic group is a migrant. Bunjevci and Romanians also have a small share of migrants $(29.4 \%)$, Ruthenians (31.6\%), Hungarians (32.4\%) and Roma (37.3\%). The largest number of Roma migrants are returnees from Germany, Austria, Switzerland, Sweden or some other European country [9] in which they lived and worked until the adoption of the 2007 readmission law, since a considerable number of Roma people were deported to Serbia. In Vojvodina, migrants who have resettled within the Republic of Serbia are dominant (63.0\%). Those who immigrated from abroad are mostly migrants, that is, refugees from the former republics of the SFRY. Such a structure of migrants is present in Serbs, Croats and Montenegrins. Other ethnic groups are dominated by resettlement within Serbia. Migrants from other countries dominate in Romanians, Hungarians and Slovaks, that is, these are migrations that are related to the motherland (Table 1).

Table 1. Indigenous and settled population of the Region of Vojvodina by ethnic groups, in 2011

\begin{tabular}{|c|c|c|c|c|c|c|c|c|}
\hline \multirow{3}{*}{ Ethnic groups } & \multirow{3}{*}{ Total } & \multirow{3}{*}{$\begin{array}{l}\text { Living in } \\
\text { the same } \\
\text { settlement } \\
\text { from birth }\end{array}$} & \multicolumn{6}{|c|}{ Settled to a settlement of permanent residence } \\
\hline & & & \multirow[b]{2}{*}{ Total } & \multirow{2}{*}{$\begin{array}{l}\text { Settled from the } \\
\text { territory of the } \\
\text { Republic of } \\
\text { Serbia }\end{array}$} & \multicolumn{3}{|c|}{ From abroad } & \multirow{2}{*}{$\begin{array}{l}5 \\
0 \\
0 \\
\frac{E}{5} \\
5\end{array}$} \\
\hline & & & & & Total & $\begin{array}{c}\text { Former } \\
\text { Republics of } \\
\text { SFRY }\end{array}$ & $\begin{array}{l}\text { Other } \\
\text { countries }\end{array}$ & \\
\hline $\begin{array}{l}\text { Region of } \\
\text { Vojvodina }\end{array}$ & 100.0 & 53.8 & 46.2 & 63.0 & 37.0 & 92.0 & 8.0 & 0.01 \\
\hline Serbs & 100.0 & 48.9 & 51.1 & 58.2 & 41.8 & 95.5 & 4.5 & 0.01 \\
\hline Bunjevci & 100.0 & 70.6 & 29.4 & 94.8 & 5.2 & 44.4 & 55.6 & 0.01 \\
\hline Hungarians & 100.0 & 67.6 & 32.4 & 92.3 & 7.7 & 31.7 & 68.3 & 0.01 \\
\hline Rom & 100.0 & 62.7 & 37.3 & 87.6 & 12.3 & 42.0 & 58.0 & 0.02 \\
\hline Romanians & 100.0 & 70.6 & 29.4 & 82.3 & 17.7 & 11.5 & 88.5 & 0.00 \\
\hline Ruthenains & 100.0 & 68.4 & 31.6 & 88.7 & 11.3 & 68.7 & 31.3 & 0.00 \\
\hline Slovaks & 100.0 & 76.8 & 23.2 & 87.9 & 12.1 & 42.7 & 57.3 & 0.01 \\
\hline Croats & 100.0 & 55.7 & 44.3 & 51.7 & 48.2 & 93.7 & 6.3 & 0.01 \\
\hline Montenegrins & 100.0 & 50.6 & 49.4 & 48.9 & 51.0 & 98.1 & 1.9 & 0.02 \\
\hline
\end{tabular}


In the period from 2001 to 2015 , the Serbs were the most movable ethnic group in terms of permanent internal migration. More than $50.0 \%$ of migrants who moved within the borders of Serbia were Serbs. All other ethnic groups have significantly smaller shares. As indicated, Serbs participate with around $66.8 \%$, so that their dominance in emigration and immigration is the result of the fact that they make two thirds of the population of Vojvodina. Interestingly, migrations were more intense in the first decade of the $21 \mathrm{st}$ century, and then in the second decade there was a decrease in intensity, which is typical for all ethnic groups (Table 2).

Table 2. Immigrants and emigrants in the territory of the Region of Vovjodina by ethnicity, in the period from 2001 to 2015 (\%)

\begin{tabular}{|c|c|c|c|c|c|c|c|c|c|c|c|c|}
\hline & & & & & & & & & & & & \\
\hline Periods & 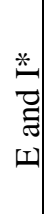 & 吾 & 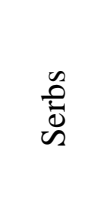 & 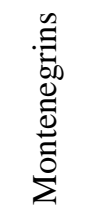 & 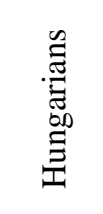 & $\begin{array}{l}\widetilde{\Xi} \\
\stackrel{\Xi}{\simeq}\end{array}$ & 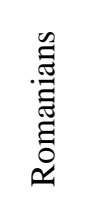 & 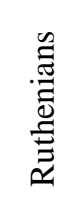 & 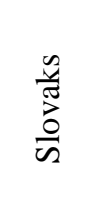 & 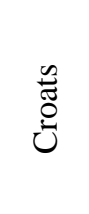 & 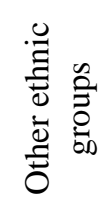 & 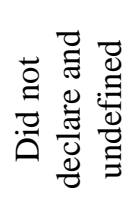 \\
\hline $2001-$ & $\mathrm{I}$ & 137508 & 67785 & 1919 & 12302 & 2818 & 1042 & 574 & 1268 & 2553 & 9401 & 37846 \\
\hline 2005 & $\mathrm{E}$ & 126015 & 62675 & 2116 & 12134 & 2302 & 1088 & 568 & 1203 & 2618 & 10205 & 31106 \\
\hline 2006- & $\mathrm{I}$ & 144255 & 70770 & 2152 & 11817 & 3066 & 906 & 586 & 1150 & 2173 & 7740 & 43895 \\
\hline 2010 & $\mathrm{E}$ & 149611 & 71802 & 2476 & 11890 & 2396 & 973 & 587 & 1183 & 2298 & 8542 & 47464 \\
\hline $2011-$ & $\mathrm{I}$ & 159543 & 73973 & 1924 & 11245 & 3417 & 867 & 500 & 1182 & 1925 & 13299 & 51211 \\
\hline 2015 & $\mathrm{E}$ & 163389 & 75285 & 2089 & 11365 & 3053 & 929 & 516 & 1202 & 2019 & 15020 & 51911 \\
\hline
\end{tabular}

Source: [10]

As with emigration, immigrants in Vojvodina are mostly Serbs (Table 2). The immigration is of lower intensity, both in Serbs and in other ethnic groups, during the second decade of the 21 st century. Reduction in migration volume and emigration domination is the result of economic events, the calming of the political situation, foreign investments and the initiation of some forms of production, but also due to decreased migration potential in Serbia, that is, in the area of Vojvodina. The emigration domination may be the result of an increased emigration volume in this century. Most of the relocations within the country were in relation of smaller town - larger cities. During the last decade, there has been a smaller number of migrants from rural areas due to leaving villages during the second half of the 20th century. But, on the other hand, the cities, due to the closure of numerous factories, do not offer the possibility of fast employment, so they do not attract the population as before. Today, the largest number of population is directed towards Belgrade and Novi Sad. Between the last two censuses only Novi Sad had a population growth, precisely because of migration.

The economically active population in Vojvodina, who persuade professions, is mostly moving within the same municipality (52.3\%). Almost a quarter of them move within the same area, but other municipality, and almost a quarter of migrants travel daily for work to other areas. The Serbian population, which is majority and has such daily movement of migrants, in Serbia and Vojvodina, has just led to such a schedule of daily migrants at the level of Vojvodina. Active Bunjevci mostly persuade professions within the same municipality $(87.2 \%)$, and a small percentage of them migrates to other area $(7.9 \%)$ and to other municipalities in the same area (4.7\%). About two-thirds of the Hungarian, Romany, Romanian, Croat and Slovakian active populations who persuade professions 
work within one municipality. There is the largest number of active Montenegrins who work in other municipality (30.5\%). In addition, the largest number of active Montenegrins, as Serbs, migrates to other areas to persuade their professions. The largest percentage of active Hungarians (1.2) and Roma (1.4\%) persuade their professions in foreign countries. Due to proximity of the border with the country of origin, Hungarians migrate over border for work, while the Roma population work seasonally abroad and return to Serbia (Table 3).

Table 3. Share of the daily migrants of the economically active population that persuade professions, by ethnicity, $2011(\%)$

\begin{tabular}{|c|c|c|c|c|c|}
\hline & \multicolumn{5}{|c|}{ Active population that persuade professions } \\
\hline & \multirow[b]{2}{*}{ total } & \multicolumn{2}{|c|}{ In the same area } & \multirow[b]{2}{*}{$\begin{array}{c}\text { in other } \\
\text { area }\end{array}$} & \multirow[b]{2}{*}{$\begin{array}{l}\text { in foreign } \\
\text { country }\end{array}$} \\
\hline & & $\begin{array}{l}\text { within the same } \\
\text { municipality }\end{array}$ & $\begin{array}{c}\text { in other } \\
\text { municipality }\end{array}$ & & \\
\hline Region of Vojvodina & 100.0 & 52.3 & 24.2 & 23.2 & 0.4 \\
\hline Serbs & 100.0 & 50.3 & 24.7 & 24.8 & 0.2 \\
\hline Bunjevci & 100.0 & 87.2 & 4.7 & 7.9 & 0.2 \\
\hline Hungarians & 100.0 & 62.4 & 20.4 & 16.0 & 1.2 \\
\hline Roma & 100.0 & 67.4 & 13.8 & 17.4 & 1.4 \\
\hline Romanians & 100.0 & 68.3 & 18.6 & 12.6 & 0.5 \\
\hline Ruthenians & 100.0 & 57.3 & 25.6 & 16.9 & 0.2 \\
\hline Slovaks & 100.0 & 59.3 & 25.5 & 14.8 & 0.3 \\
\hline Croats & 100.0 & 61.3 & 22.1 & 15.7 & 0.8 \\
\hline Montenegrins & 100.0 & 44.0 & 30.5 & 25.2 & 0.3 \\
\hline Others & 100.0 & 43.1 & 30.3 & 26.0 & 0.6 \\
\hline Undeclared & 100.0 & 52.7 & 25.8 & 21.0 & 0.6 \\
\hline Regional Affiliation & 100.0 & 43.2 & 34.6 & 21.6 & 0.6 \\
\hline Unknown & 100.0 & 49.2 & 20.3 & 30.0 & 0.5 \\
\hline
\end{tabular}

The active population of all ethnic groups most often persuade their professions within the municipality in which they live. Montenegrins, Serbs, Ruthenians and Slovaks migrate mostly within the same area, but also to other municipalities, and Montenegrins and Serbs are most active and migrate mostly to other areas.

Table 4. Share of daily migrants of pupils and students, by ethnicity, $2011(\%)$

\begin{tabular}{|c|c|c|c|c|c|}
\hline & \multicolumn{5}{|c|}{ Pupils/students who studying } \\
\hline & \multirow[b]{2}{*}{ total } & \multicolumn{2}{|c|}{ In the same area } & \multirow{2}{*}{$\begin{array}{l}\text { In other } \\
\text { area }\end{array}$} & \multirow{2}{*}{$\begin{array}{l}\text { In foreign } \\
\text { country }\end{array}$} \\
\hline & & $\begin{array}{l}\text { Within the same } \\
\text { municipality }\end{array}$ & $\begin{array}{c}\text { In other } \\
\text { municipality }\end{array}$ & & \\
\hline Region of Vojvodina & 100,0 & 37,1 & 28,5 & 33,3 & 1,1 \\
\hline Serbs & 100,0 & 37,0 & 27,9 & 34,8 & 0,3 \\
\hline Bunjevci & 100,0 & 71,8 & 8,7 & 19,1 & 0,4 \\
\hline Hungarians & 100,0 & 35,8 & 29,2 & 28,9 & 6,1 \\
\hline Roma & 100,0 & 62,8 & 25,1 & 12,0 & 0,1 \\
\hline Romanians & 100,0 & 50,7 & 27,4 & 12,9 & 9,1 \\
\hline Ruthenians & 100,0 & 31,3 & 30,5 & 38,2 & 0,0 \\
\hline Slovaks & 100,0 & 31,9 & 45,9 & 22,1 & 0,1 \\
\hline Croats & 100,0 & 49,7 & 22,8 & 25,1 & 2,3 \\
\hline Montenegrins & 100,0 & 18,9 & 38,5 & 42,0 & 0,6 \\
\hline Others & 100,0 & 34,7 & 28,0 & 37,3 & 0,0 \\
\hline Undeclared & 100,0 & 36,4 & 29,4 & 33,4 & 0,7 \\
\hline Regional Affiliation & 100,0 & 23,4 & 34,1 & 42,0 & 0,5 \\
\hline
\end{tabular}


The daily migration of pupils and students is somewhat different in relation to the daily movement of the active population that persuades profession. Pupils and students migrate most often within a municipality or other area. Pupils and students of the Bunjevac ethnic group mostly stay in one municipality (Table 4). On the other hand, Montenegrins migrate least within one municipality. Pupils of the Montenegrin ethnic group are the most movable within one area, and often migrate to another area. Pupils migrate mainly during secondary education. Secondary schools are most often located in centers of municipalities, thus pupils from other settlements of one municipality migrate during the day to the center of the municipality. A certain number of pupils migrate to other municipalities, and there are few who migrate to another area. On the other hand, students most often migrate to other areas, because universities are located mainly in larger city centers, such as Novi Sad. But besides this largest Vojvodina settlement, there are faculties in Subotica, Zrenjanin, Sombor, thus students migrate towards them.

\section{CONCLUSION}

Serbs, followed by Montenegrins, are the two most movable ethnic groups in permanent or daily migration of the population of Vojvodina. Over the past centuries, both ethnic groups have been forced to frequently change their place of residence, under the influence of war events in those areas. Over the past centuries, Serbs have been forced into exile several times. This resulted in the fact that even today, the majority ethnic group in Serbia and Vojvodina has the largest percentage of the migrant population. As the majority population in Vojvodina, they make the largest number of emigrants and immigrants in all the years of the 21 st century. They are also active in the daily movements of the population. On the other hand, some indigenous groups are quite closed, such as Bunjevci, Romanians and Slovaks who have a smaller percentage of the migrant population. A smaller migration volume of these ethnic groups is also influenced by their higher mean age. The older population is less movable and less likely to migrate than the young population.

During the last decade, Serbia experiences emigration of the population, which includes all ethnic groups, which will result in further reduction in the volume of internal migrations, as well as daily migrations. The large outflow of the young population will

have a negative effect on the economic development of the country, because they should form the human resource as a base of economic development.

\section{REFERENCES}

[1] Mathieson, I., Roodenberg, S. A., Posth, C., Szécsényi-Nagy, A., Rohland, N., Mallick, S., ... $\&$ Ferry, M. (2018). The genomic history of southeastern Europe. Nature, February, doi:10.1038/nature25778.

[2] Bubalo-Živković, M., (2017), Starost etničkih grupa na prostoru Vojvodine. U: Etničke grupe Vojvodine u 21. veku - stanje i perspektive održivosti - E-book. str. 18-45, ISBN 978-86-7031430-6.

[3] Stojšin, S., 2015, Ethnic Diversity of Population in Vojvodina at the Begining of the 21st Century. European Quarterly of Political Attitudes and Mentalities, Vol. 4, No. 2, pp 25-37.

[4] Bubalo-Živković, M., Djerčan, B., Lukić, T., Jovanović, G., 2014, Moving to the Welfare Countries: Emigrants from Serbia 1961-2002. European Researcher, Vol. 71, No. 3-2, p 581-594. 
[5] Raduški, N., 2002, Etničke migracije na prostoru Vojvodine u drugoj polovini 20. stoljeća. Etničke i migracijske teme, Vol. 18, No. 4, str. 339-348.

[6] Statistical Office of the Republic of Serbia, 2012, Ethnicity. Data by municiplities and cities, 2011 Census of Population, Households and Dwellings in the Republic of Serbia, 1, Beograd.

[7] Statistical Office of the Republic of Serbia, 2013, Daily Migrants. Data by municiplities and cities, 2011 Census of Population, Households and Dwellings in the Republic of Serbia, 11, Beograd.

[8] Bubalo-Živković, M., Lukić, T., Đerčan, B. (2015), Emigration from Vojvodina province. Procedings Internacional scientific conference Geobalcanica 2015, 5-7 June, Skopje, Macedonia, p 299-305.

[9] Radovanović, S., Knežević, A., 2014, Romi u Srbiji. Republički zavod za statistiku, Beograd. [10] Statistical Office of the Republic of Serbia, Ethnicity, additional data processing, Census 2011.

[8] Statistical Office of the Republic of Serbia, Ethnicity, additional data processing, Census 2011.

[9] Statistical Office of the Republic of Serbia, 2013, Daily Migrants. Data by municiplities and cities, 2011 Census of Population, Households and Dwellings in the Republic of Serbia, 11, Beograd.

[10] Stojšin, S., 2015, Ethnic Diversity of Population in Vojvodina at the Begining of the 21st Century. European Quarterly of Political Attitudes and Mentalities, Vol. 4, No. 2, pp 25-37. 